\title{
Detection of freshwater cyanotoxins and measurement of masked microcystins in tilapia from Southeast Asian aquaculture farms
}

\author{
Brett Greer $^{1} \cdot$ Ronald Maul $^{2,3} \cdot$ Katrina Campbell $^{1} \cdot$ Christopher T Elliott $^{1}$
}

Received: 21 November 2016 /Revised: 2 March 2017 / Accepted: 30 March 2017 /Published online: 20 April 2017

(C) The Author(s) 2017. This article is published with open access at Springerlink.com

\begin{abstract}
Recently, there has been a rise in freshwater harmful algal blooms (HABs) globally, as well as increasing aquaculture practices. HABs can produce cyanotoxins, many of which are hepatotoxins. An ultra-performance liquid chromatography tandem mass spectrometry method was developed and validated for nine cyanotoxins across three classes including six microcystins, nodularin, cylindrospermopsin and anatoxin-a. The method was used to analyse free cyanotoxin(s) in muscle $(n=34)$, liver $(n=17)$ and egg $(n=9)$ tissue samples of 34 fish sourced from aquaculture farms in Southeast Asia. Conjugated microcystin was analysed by Lemieux oxidation to ascertain the total amount of microcystin present in muscle. Some tilapia accumulated free microcystin-LR in the muscle tissue at a mean of $15.45 \mu \mathrm{g} / \mathrm{kg}$ dry weight ( $\mathrm{dw})$, with total microcystin levels detected at a mean level of $110.1 \mu \mathrm{g} / \mathrm{kg} \mathrm{dw}$, indicating that the amount of conjugated or masked microcystin present in the fish muscle accounted for $85 \%$ of the total. Higher levels of cyanotoxin were detected in the livers, with approximately $60 \%$ of those tested being positive for microcystin-LR and microcystin-LF, along with cylindrospermopsin. Two fish from one of the aquaculture farms contained cylindrospermopsin in the eggs; the first time this has been reported. The estimated daily intake for free and total microcystins in fish muscle tissue
\end{abstract}

Brett Greer

brett.greer@qub.ac.uk

1 Institute for Global Food Security, School of Biological Sciences, Queens University Belfast, Stranmillis Road, Belfast BT9 5AG, UK

2 BAM Federal Institute for Materials Research and Testing, Richard-Willstätter-Straße 11, 12489 Berlin, Germany

3 School of Food Science, Institute of Food Chemistry, University of Hamburg, Grindelallee 117, 20146 Hamburg, Germany was 2 and 14 times higher, respectively, than the tolerable daily intake value. This survey presents the requirement for further monitoring of cyanotoxins, including masked microcystins, in aquaculture farming in these regions and beyond, along with the implementation of guidelines to safeguard human health.

Keywords Harmful algal bloom · UPLC-MS/MS ·

Aquaculture $\cdot$ Microcystin $\cdot$ Bioaccumulation $\cdot$ Human health

\section{Introduction}

Harmful algal blooms (HABs), found in aquatic environments across the globe, are formed when certain cyanobacterial bloom exponentially producing secondary metabolites called cyanotoxins. Approximately 40 cyanobacterial species have been identified as being capable of producing these cyanotoxins $[1,2]$. One such cyanobacterium, Microcystis aeruginosa, is known to produce the cyanotoxin microcystin (MC) of which around 100 different congeners have been characterised to date and which has widespread occurrence globally [3]. Another producer, Cylindrospermopsis raciborskii, is rapidly spreading with its bioactive metabolite cylindrospermopsin (CYN) reported in several countries [4]. Of particular importance are the hepatotoxins comprising the cyclic peptides (MCs and nodularin (NOD)), the tricyclic alkaloid (CYN) as well as the potent neurotoxin (anatoxin-a (ATX-A)), with the structures outlined in Fig. $1[2,5]$. The $\mathrm{MC}$ congeners are cyclic heptapeptides, with structural variations coming from differences in the amino acids at positions 2 and 4 within the cyclic body of the molecule.

The MCs and NOD are potent hepatotoxins, known to cause liver failure by their inhibition of protein phosphatase type 1 (PP1) and protein phosphatase type 2A (PP2A) in liver cells [6]. This happens through the 
a

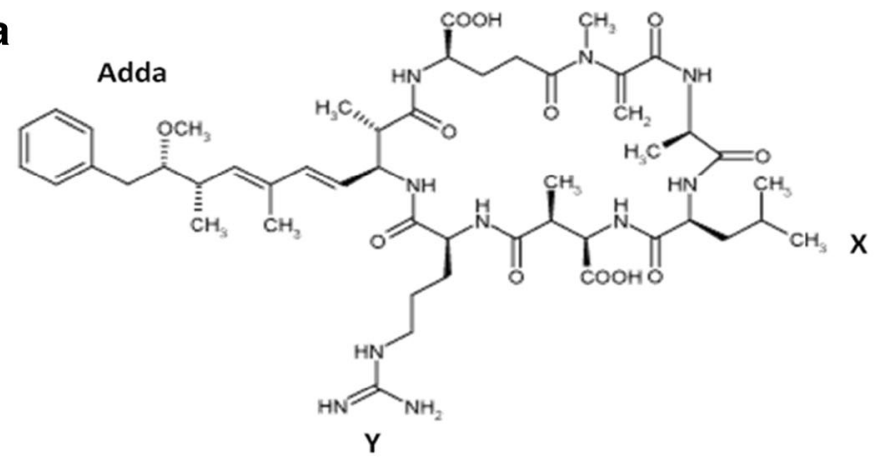

C<smiles>CC1C(OS(=O)(=O)O)C[C@H]2C[C@@H]([C@H](O)c3cc(=O)[nH]c(=O)[nH]3)NC(=N)N12</smiles>

\begin{tabular}{|l|l|l|}
\hline Congener & $\mathrm{X}$ & $\mathrm{Y}$ \\
\hline MC-LR & Leucine (L) & Arginine (R) \\
\hline MC-YR & Tyrosine $(\mathrm{Y})$ & Arginine (R) \\
\hline MC-RR & Arginine (R) & Arginine (R) \\
\hline MC-LA & Leucine (L) & Alanine (A) \\
\hline MC-LY & Leucine (L) & Tyrosine (Y) \\
\hline MC-LF & Leucine (L) & Phenylalanine (F) \\
\hline
\end{tabular}

b

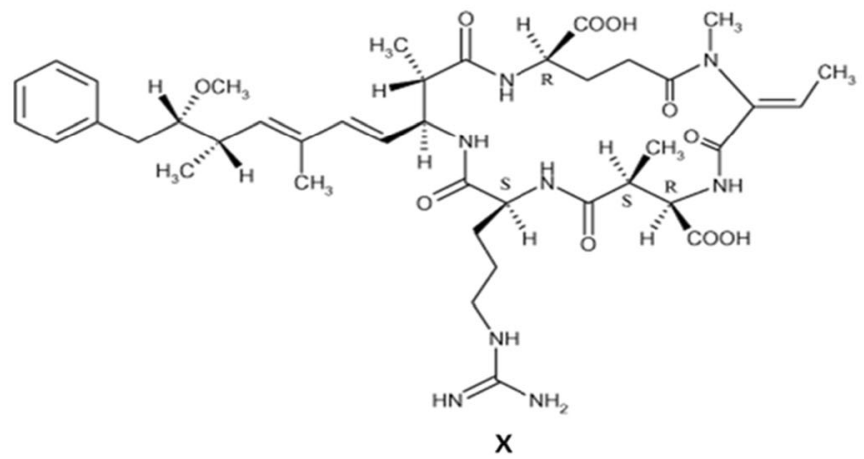

Fig. 1 Chemical structures of the a cyclic heptapeptide microcystin-LR with $X$ and $Y$ being the variable amino acids as indicated in the accompanying table; b cyclic pentapeptide nodularin, with only one

formation of a non-covalent bond between the $\beta$-amino acid 3-amino-9-methoxy-2,6,8-trimetyl-10-phenyldeca4,6-dienoic acid (Adda) side chain and the glutamyl carboxyl, followed by a covalent, irreversible bond formed between the $\mathrm{N}$-methyldehydroalanine (Mdha) group of the toxin and cysteine residue(s) of the protein phosphatase. There is also evidence indicating MC-LR as a tumour promoter, as in 2010, it was classified as a group 2B carcinogen by the IARC, whose evaluation deemed it as possibly being carcinogenic to humans [7].

Another of the cyanotoxins, CYN, is a known inhibitor of protein synthesis across multiple organ systems such as the liver and kidneys, with the liver being the primary target organ for bioaccumulation and toxicity. Because of its impact on other organs, CYN can also be regarded as a general cytotoxin, with its mode of action mediated through inhibition of protein synthesis and cytochrome P450, variable amino acid ( $\mathrm{X}=$ arginine), the most common congener; $\mathbf{c}$ tricyclic alkaloid cylindrospermopsin (CYN); and $\mathbf{d}$ the alkaloid anatoxin-A (ATX-A)

as well as genotoxicity caused by DNA fragmentation. Furthermore, it has also been suggested that CYN could be classified a potential carcinogen [8].

The neurotoxin, ATX-A, interferes with transmission of nerve impulses as it mimics the neurotransmitter acetylcholine. It acts as a potent cholinergic blocking agent and can compete with acetylcholine for the nicotinic and muscarinic receptors. Exposure results in overstimulation of the receptors leading to persistent muscle stimulation and subsequent death due to muscular paralysis and respiratory failure [2]. The ingestion of cyanotoxins through drinking water has been implicated in the poisonings of both humans and animals [2,9], with human poisonings documented across continents such as North and South America, Europe and Asia [3]. One incident, in particular, resulted in numerous human fatalities when patients undergoing renal dialysis were exposed to MCs in Caruara, Brazil [10]. 
Increasing reports of the bioaccumulation of cyanotoxins in freshwater seafood have been extensively reviewed [11, 12] with the warning that human exposure through this route may be underestimated. A study on fishermen subsisting from Lake Chaohu in China showed MCs in the water, accumulation of these toxins in the fish and subsequent uptake into the serum of the fishermen through fish consumption. Additional investigation of liver function enzymes indicated hepatocellular damage in these men [13]. There is also evidence to suggest that the high levels of liver cancer in regions of Southeast Asia and China could be linked to the drinking of surface water, where cyanobacteria and possibly cyanotoxins are abundant [7, 14]. More recently, it has been shown that MCLR may promote the migration and invasion of colorectal cancer and has also been implicated in renal function impairment through consumption of MC-LR-contaminated water and food $[15,16]$.

Linked to the spread of these freshwater toxins globally in aquatic environments is the increase in inland aquaculture, contributing almost $65 \%$ to the world's farmed food fish production between 2003 and 2013. The global aquaculture production of the Nile tilapia (Oreochromis niloticus) contributed almost 3.5 million tonnes in 2013 and is becoming one of the most farmed fish in the world. Since 2008, Asia has produced more fish through aquaculture with its share in total production reaching almost $90 \%$ in 2014. Almost all fish produced by aquaculture is used for direct human consumption with the remaining utilised for the manufacture of fishmeal and fish oils [17].

Due to the intensive use of freshwater resources, lake and pond water is becoming increasingly polluted with the resulting increase in nutrient load giving rise to HABs [18]. Examples of this are occurrences of dense HABs in many Chinese lakes, such as Lake Taihu, Lake Chaohu and Lake Dianchi, which have increased in frequency in recent years [19]. MCs have also been detected in 54\% of aquaculture ponds in Zaria, Northern Nigeria, with several having MC levels above the World Health Organization (WHO) limit of $1 \mu \mathrm{g} / \mathrm{L}[20]$ as well as being identified in a freshwater fishing lake in Mexico, characterised by a persistent HAB containing MCs [21]. Aquaculture species can be exposed to cyanotoxins through the aquatic food chain and can accumulate in their tissues facilitating transfer through the food chain, although their bioaccumulation or biomagnification is ambiguous depending on the species. MCs, and to a lesser extent CYN, have been shown to bioaccumulate in invertebrates such as bivalves and also in fish [11]. Accumulation of MCs has been shown in the muscle (edible) tissue of various species of fish within natural systems $[19,22,23]$. Note that, in some cases, fish can be eaten whole and, therefore, the viscera can contribute to the overall toxicity. There have also been reports of CYN in natural freshwater systems such as in the muscle of crayfish [24] and tegogolos snails from a freshwater lake in
Mexico [21]; however, although CYN was detected in the viscera of the rainbow fish Melanotaenia eachamensis in a freshwater system [24], there were no reports of this toxin in the edible parts of any fish species until a study by Berry et al. [25] showed the apparent accumulation of CYN in fish muscle across several species of fish in a freshwater lake, albeit at low levels of $<1 \mu \mathrm{g} / \mathrm{kg}$ wet weight (ww) [25].

MCs can accumulate in fish tissues as free toxin or can be found as bound/conjugated (masked) through their binding to PP1 and PP2A in certain tissues as outlined above. Once bound, they cannot be detected by conventional extraction techniques. Instead, the use of Lemieux oxidation, a technique known to produce 2-methyl-3-methoxy-4-phenylbutyric acid (MMPB) by oxidation of the Adda side chain found in each $\mathrm{MC}$ congener [26], allows for the total level of $\mathrm{MC}$ to be calculated. This value consists of both free and covalently bound $\mathrm{MC}$, allowing the total exposure to $\mathrm{MCs}$ to be ascertained.

Although hepatotoxic effects have been partially documented in humans after exposure to MCs, the effects of long-term chronic exposure to low MC levels, as well as other hepatotoxins, have not been fully investigated. The objective of this study were to (a) develop and validate a UPLC-MS/MS method for the analysis of free cyanobacterial toxins in fish (O. niloticus) across three cyanobacterial classes, (b) analyse the level of total MC (and/or NOD) present by the use of Lemieux oxidation and (c) assess the potential risk to human health through consumption of fish (O. niloticus) grown in commonly employed pond-based aquaculture farms in SE Asia.

\section{Materials and methods}

\section{Materials}

MCs (MC-LR, MC-YR, MC-RR, MC-LA, MC-LY and MCLF) and NOD standards were purchased from Enzo Life Sciences, Ltd. (UK), CYN was obtained from n'Tox (France) and ATX-A was purchased from the National Research Council, Canada. MMPB was purchased from Wako Pure Chemical Industries, Ltd. (Japan). CYN N ${ }^{15}$-labelled internal standard $\left(\mathrm{N}^{14} \rightarrow \mathrm{N}^{15}\right)$ was a gift from the Federal Institute for Materials Research and Testing (BAM), Berlin, Germany. Acetonitrile and methanol, LC-MS Chromasolv grade, dichloromethane, formic acid, trifluoroacetic acid, potassium permanganate, sodium (meta) periodate and sodium bisulfite were all purchased from Sigma-Aldrich, UK, as were the ENVI-Carb solid-phase extraction (SPE) cartridges $\left(250 \mathrm{mg}, 3 \mathrm{~cm}^{3}\right)$. Oasis HLB and PRiME SPE cartridges $\left(60 \mathrm{mg}, 3 \mathrm{~cm}^{3}\right)$ were purchased from Waters, Ireland. The water used was supplied from an in-house Milli-Q water system (Millipore, Ltd., UK), with 
conductivity and total organic content (TOC) of the water being $18 \mathrm{M} \Omega$ and $3 \mathrm{ppb}$, respectively.

\section{Standard preparation}

The ATX-A standard was provided at a concentration of $4.96 \mu \mathrm{g} / \mathrm{mL}$. The MCs, NOD and CYN were purchased in $100 \mu \mathrm{g}$ quantities, with their identity confirmed by MS and purity being $\geq 95 \%$ as verified by HPLC, according to the certificate of analysis. Stock standards of $1 \mathrm{mg} / \mathrm{mL}$ of each cyanotoxin were carefully prepared by reconstitution of the product in the vial by the addition of $100 \mu \mathrm{L}$ of pure methanol or, in the case of CYN, pure water. Working standards at a concentration of $10 \mu \mathrm{g} / \mathrm{mL}$ were then prepared by diluting stock standards $(1: 100 \mathrm{v} / \mathrm{v})$ with $80 \%$ aqueous methanol $(\mathrm{v} /$ $v$ ) and water for CYN. The multi-toxin standard used to make the calibrants was prepared at a concentration of $0.5 \mu \mathrm{g} / \mathrm{mL}$ by dilution of the $10 \mu \mathrm{g} / \mathrm{mL}$ working standards 1:20 $(\mathrm{v} / \mathrm{v})$ and in the case of ATX-A by 1:9.92 $(v / v)$ with $80 \%$ aqueous metha$\operatorname{nol}(v / v)$.

\section{Ultra-performance liquid chromatography tandem mass spectrometry}

\section{Free cyanotoxin analysis}

Separation and analysis of the nine cyanotoxins were carried out using an ACQUITY UPLC i-Class system coupled to a Xevo TQ-MS mass spectrometer (Waters, Manchester, UK) using multiple reaction monitoring (MRM) as detailed in Greer et al. [4], with the transitions used for the analysis outlined in Table 1. Separation was achieved on an ACQUITY UPLC HSS T3 column, $100 \mathrm{~mm} \times 2.1 \mathrm{~mm}$ i.d., $1.8 \mu \mathrm{m}$ particle size and $130 \AA$ pore size (Waters, UK), in order to retain the polar CYN [27]. The two mobile phases consisted of water containing $0.1 \%$ formic acid $(v / v)$ and the organic solvent, acetonitrile. The flow rate was set at $0.45 \mathrm{~mL} /$ min with the acetonitrile held at $2 \%$ for $1 \mathrm{~min}$, followed by an increase to $70 \%$ over $9 \mathrm{~min}$, maintained at $90 \%$ for $1 \mathrm{~min}$ before returning to $2 \%$ for a 1 -min re-equilibration before the next injection, with the injection volume set at $1 \mu \mathrm{L}$.

\section{Total microcystin analysis}

Analysis of MMPB and MC-LR was carried out on the same LC-MS/MS system as outlined in the "Free cyanotoxin analysis" section. Detection and quantification were achieved using MRM with the system operated in both $\mathrm{ES}^{+}$and $\mathrm{ES}^{-}$, and the transitions were optimised manually (Table 1). Separation of MMPB and MC-LR was achieved on an ACQUITY UPLC BEH C18, with column dimensions of $2.1 \mathrm{~mm} \times 50 \mathrm{~mm}, 1.8 \mu \mathrm{m}$ particle size and $130 \AA$ pore size (Waters, UK), maintained at $40{ }^{\circ} \mathrm{C}$. The mobile phases comprised of water $(0.1 \%$ acetic acid $v / v)$ and acetonitrile with the flow rate set at $0.40 \mathrm{~mL} / \mathrm{min}$. The acetonitrile was held at $10 \%$ for $0.5 \mathrm{~min}$, increased to $80 \%$ over $4 \mathrm{~min}$ and washed for $1 \mathrm{~min}$ at $90 \%$ before returning to $10 \%$ for a $1 \mathrm{~min}$ reequilibration before the next injection. The injection volume was set at $1 \mu \mathrm{L}$.

\section{Extraction of cyanotoxins in water and validation of the extraction method in fish}

Extraction, analysis and quantification of cyanotoxins in the $50 \mathrm{~mL}$ water samples collected from the five aquaculture farms were performed exactly as outlined in Greer et al. [4].

Toxin extraction and subsequent enrichment from the fish were performed according to modified methods [28, 29] and developed using 100-mg aliquots of lyophilised homogenised blank fish muscle. Extraction efficiency, reported as absolute recovery, was determined by spiking fish muscle before and after with $50 \mu \mathrm{L}$ of a multi-toxin standard at $0.5 \mu \mathrm{g} / \mathrm{mL}$, equating to a toxin level of $0.25 \mu \mathrm{g} / \mathrm{g}$ dry weight (dw) fish tissue, and $15 \mu \mathrm{L}$ of the $\mathrm{N}^{15}$-labelled CYN internal standard $\left(\mathrm{N}^{14} \rightarrow \mathrm{N}^{15}\right)$ at $1 \mu \mathrm{g} / \mathrm{mL}$.

Validation of the method for fish muscle was performed according to the European decision 2002/657/EC concerning the performance of analytical methods for banned and controlled substances in animals used for food production [30] and was achieved using 100-mg aliquots of lyophilised blank fish muscle. The blank fish muscle used for validation consisted of pooled lyophilised muscle tissue taken from fish from aquaculture farms 1-3 and 1-4. The fish muscle and water from these farms had been shown to be negative for any of the cyanotoxins tested and would maximise variability in performance as well as allowing use of an exact matrix match.

Validation involved the extraction of 20 blank samples over three separate days followed by extraction of 20 spiked samples at $0.05 \mu \mathrm{g} / \mathrm{g} \mathrm{dw}$ (addition of $10 \mu \mathrm{L}$ of the multi-toxin standard at $0.5 \mu \mathrm{g} / \mathrm{mL}$ ) extracted over three separate days. A seven-point extracted matrix-matched calibration curve was prepared in the range $0.01-0.5 \mu \mathrm{g} / \mathrm{g} \mathrm{dw}$. Each sample, including blanks and calibrants, was also spiked with $15 \mu \mathrm{L}$ of the CYN Internal Standard $\left(\mathrm{N}^{14} \rightarrow \mathrm{N}^{15}\right)$ at $1 \mu \mathrm{g} / \mathrm{mL}$. Samples were extracted and analysed as outlined below, giving the inter- and intra-day precision, trueness, absolute recovery, linearity as well as $\mathrm{CC}_{\alpha}$ (LOD) and $\mathrm{CC}_{\beta}$ (LOQ) values.

Briefly, samples $(100 \mathrm{mg})$ were extracted by the addition of $1 \mathrm{~mL}$ of $75 \%$ aqueous methanol $(v / v)(0.5 \%$ acetic acid $v / v)$, vortex mixed briefly and sonicated at room temperature for $45 \mathrm{~min}$ before centrifugation at $16,000 \mathrm{~g}$ for $15 \mathrm{~min}$. The supernatant was removed and diluted fivefold by the addition of water for loading onto SPE cartridges, with samples loaded onto the Oasis HLB cartridge, and the flow through collected then passed through ENVI cartridges. Oasis HLB cartridges 
Table 1 Table showing the optimised MRM transitions for the nine cyanotoxins, the $\mathrm{N}^{15}$ labelled cylindrospermopsin internal standard $\left(\mathrm{N}^{14} \rightarrow \mathrm{N}^{15}\right)$ and MMPB

\begin{tabular}{|c|c|c|c|c|c|c|c|}
\hline Compound & $\begin{array}{l}\text { MRM } \\
\text { function }\end{array}$ & $\begin{array}{l}\text { Precursor } \\
\text { ion }(m / z)\end{array}$ & $\begin{array}{l}\text { Cone } \\
\text { voltage } \\
\text { (V) }\end{array}$ & $\begin{array}{l}\text { Base } \\
\text { fragment ion } \\
(m / z)[Q]\end{array}$ & $\begin{array}{l}\text { Collision } \\
\text { energy } \\
(\mathrm{eV})\end{array}$ & $\begin{array}{l}\text { Qualifier } \\
\text { fragment ion } \\
(\mathrm{m} / z)[q]\end{array}$ & $\begin{array}{l}\text { Collision } \\
\text { energy } \\
(\mathrm{eV})\end{array}$ \\
\hline ATX-A ${ }^{a}$ & 1 & 166.1 & 25 & 149 & 15 & 131.1 & 16 \\
\hline CYN & 2 & 416.2 & 35 & 194.1 & 42 & 336.2 & 22 \\
\hline $\begin{array}{l}\mathrm{CYN} \\
\left(\mathrm{N}^{14} \rightarrow\right. \\
\left.\mathrm{N}^{15}\right)\end{array}$ & 3 & 421.1 & 40 & 197.1 & 40 & - & - \\
\hline MC-RR & 4 & 520.0 & 35 & 135.0 & 28 & 127.1 & 42 \\
\hline NOD & 5 & 825.5 & 65 & 135.0 & 64 & 70.0 & 78 \\
\hline MC-LA & 6 & 910.5 & 30 & 135.1 & 64 & 163.1 & 44 \\
\hline MC-LF & 7 & 986.5 & 35 & 135.1 & 70 & 213.1 & 56 \\
\hline MC-LR & 8 & 995.6 & 65 & 135.0 & 76 & 107.1 & 80 \\
\hline MC-LY & 9 & 1002.5 & 35 & 135.2 & 68 & 163.1 & 62 \\
\hline MC-YR & 10 & 1045.5 & 60 & 135.2 & 72 & 107.1 & 75 \\
\hline MMPB $^{b}$ & 1 & 209.15 & 10 & 191.2 & 5 & 131.1 & 15 \\
\hline MC-LR ${ }^{b}$ & 2 & 496.5 & 25 & 487.4 & 12 & 128.1 & 25 \\
\hline
\end{tabular}

The table is adapted and reproduced from Greer et al. [4]

$Q=$ quantifier ion, $q=$ qualifying ion

${ }^{\text {a }}$ Has a second qualifier $(q 1)$ used as a diagnostic ion to prevent misidentification: $q 1=166.1>42.95$ (not shown in the table)

${ }^{\mathrm{b}}$ Signifies the transitions used in the analysis of MMPB to determine the total amount of microcystin present were washed with water and $20 \%$ aqueous methanol $(v / v)$. Bound toxins were eluted into clean glass tubes with $2 \times 1.5 \mathrm{~mL}$ of $80 \%$ aqueous methanol $(v / v)$ containing $0.1 \%$ trifluoroacetic acid $(v / v)$ for the Oasis and $2 \times 1.5 \mathrm{~mL}$ methanol/dichloromethane $(4: 1 \mathrm{v} / \mathrm{v})$ containing $5 \%$ formic acid $(v / v)$ for the ENVI. The resulting eluents were combined, dried under a stream of nitrogen before reconstitution in $200 \mu \mathrm{L}$ of $80 \%$ aqueous methanol $(v / v)$ and transferred to a microvial for analysis.

The same method was applied for the extraction of toxins from liver tissue and eggs but was validated for fish muscle only due to the lack of material.

\section{Lemieux oxidation and extraction of MMPB}

Oxidation of bound MC and subsequent extraction were performed according to a modified method [26] and developed using 50-mg aliquots of lyophilised homogenised fish muscle. A 50-mg aliquot of fish was weighed into a $50-\mathrm{mL}$ round bottomed flask, and $5 \mathrm{~mL}$ of oxidation solution was added, comprising both potassium permanganate $\left(\mathrm{KMnO}_{4}\right)$ and sodium (meta) periodate $\left(\mathrm{NaIO}_{4}\right)$, each at $0.1 \mathrm{M}$, stirred at room temperature for $2 \mathrm{~h}$. When the colour of the solution turned from purple (colour of $\mathrm{KMnO}_{4}$ ) to red/brown (reduced product colour), a further $3 \mathrm{~mL}$ oxidation solution $(0.1 \mathrm{M})$ was added, turning the solution back to purple. The reaction was immediately quenched by the addition of $1 \mathrm{~mL}$ sodium bisulphite solution $(40 \% \mathrm{w} / \mathrm{v})$, and $10 \%$ sulphuric acid was added drop-wise until the $\mathrm{pH}$ was acidic ( 2). Samples were then centrifuged at $4500 \mathrm{rpm}$ for $15 \mathrm{~min}$, and the resulting supernatant was removed and loaded onto SPE columns.

Sample enrichment was achieved using Oasis PRiME cartridges, with these not requiring any conditioning. Samples were loaded onto the cartridges and washed with water and then $20 \%$ aqueous methanol $(v / v)$. Bound MMPB was eluted into clean glass tubes with $2 \times 1.5 \mathrm{~mL}$ of $80 \%$ aqueous methanol $(v / v)$. The eluents were evaporated to dryness under a gentle stream of nitrogen, reconstituted in $200 \mu \mathrm{L}$ of $50 \%$ aqueous methanol $(v / v)$ and transferred to a microvial for analysis.

\section{Evaluation of cyanotoxins in fish samples}

\section{Field sample preparation}

Field samples ( $n=60 ; 34$ fish muscle, 17 livers and 9 egg samples) as well as $50 \mathrm{~mL}$ water samples $(n=5)$ were collected from five aquaculture farms across SE Asia. Each fish was gutted and filleted separately with any liver or egg samples found also excised for analysis. All fish samples were lyophilised using a Christ freeze-dryer (Osterode, Germany) to increase the surface area for extraction of the cyanotoxins, allowing for a greater biomass to extraction solvent ratio, enhancing the extraction efficiency. This step enabled the extract to be spun at a higher speed to obtain a cleaner supernatant and to reduce the loading volume and time for the SPE clean-up. The supernatant for SPE must be diluted fivefold, whereby a larger starting mass requires a larger extraction 
volume and, subsequently, a larger loading volume after dilution, increasing the time to load both cartridges. After lyophilisation, samples were homogenised using a Retsch Ball Mill (Haan, Germany) before storage at $-20{ }^{\circ} \mathrm{C}$ prior to extraction and analysis. Water samples were lyophilised using a Christ freeze-dryer (Osterode, Germany) and stored at $-20^{\circ} \mathrm{C}$ prior to extraction and analysis.

\section{Analysis of free cyanotoxin content in fish}

Samples $(100 \mathrm{mg})$, including liver and eggs, were weighed into a 2-mL tube and spiked with $15 \mu \mathrm{L}$ of the $\mathrm{N}^{15}$-labelled CYN internal standard $\left(\mathrm{N}^{14} \rightarrow \mathrm{N}^{15}\right)$ at $1 \mu \mathrm{g} / \mathrm{mL}$. Toxin extraction and subsequent enrichment were carried out as outlined above in the "Extraction of cyanotoxins in water and validation of the extraction method in fish" section. In order to quantify any toxins identified, a six-point extracted matrix-matched calibration curve in the range $0.005-0.1 \mu \mathrm{g} / \mathrm{g}$ $\mathrm{dw}$ using pooled blank tilapia muscle tissue was prepared as above, with the calibrant levels achieved by spiking with a multi-toxin standard at $0.1 \mu \mathrm{g} / \mathrm{mL}$ along with $15 \mu \mathrm{L}$ of the $\mathrm{N}^{15}$-labelled CYN internal standard $\left(\mathrm{N}^{14} \rightarrow \mathrm{N}^{15}\right)$ at $1 \mu \mathrm{g} / \mathrm{mL}$.

\section{Analysis of total microcystin content in muscle samples}

Fish muscle samples $(50 \mathrm{mg})$ were weighed into $50-\mathrm{mL}$ round bottomed flasks with the conversion and subsequent enrichment of MMPB carried out as outlined above in the "Lemieux oxidation and extraction of MMPB" section. In order to quantify any MMPB detected, a seven-point extracted matrixmatched calibration curve in the range $0.025-1 \mu \mathrm{g} / \mathrm{g}$ dry weight using pooled blank tilapia was used, with the levels achieved by spiking with the MMPB standard at $0.5 \mu \mathrm{g} / \mathrm{mL}$ after $\mathrm{pH}$ adjustment.

\section{Results}

\section{UPLC-MS/MS development for total microcystin (MMPB)}

Detection and analysis of MMPB, and of MC-LR to confirm complete oxidation, were initially examined using negative polarity $\left(\mathrm{ES}^{-}\right)$as both analytes can form the $[\mathrm{M}-\mathrm{H}]^{-}$ion, although MC-LR was seen as $[\mathrm{M}-2 \mathrm{H}]^{2-}$. This was achieved using mobile phases comprised of water containing $0.1 \%$ acetic acid $(v / v)$ and acetonitrile and was compared to the analysis of MMPB and MC-LR using positive polarity $\left(\mathrm{ES}^{+}\right)$with the same mobile phases, as well as changing the additive in the aqueous mobile phase to $0.1 \%$ formic acid $(v /$ $v)$. The sensitivity of the MMPB product ions and, in particular, the qualifying ion $(q)$ in negative polarity was too weak, especially in the matrix. The best sensitivity for the analytes was observed by the use of $0.1 \%$ acetic acid $(v / v)$ in the aqueous mobile phase, with $\mathrm{ES}^{+}$chosen as the mode of analysis for MMPB as an $[\mathrm{M}+\mathrm{H}]^{+}$ion, whereas MC-LR proved better as an $[\mathrm{M}-2 \mathrm{H}]^{2-}$ ion.

\section{Method validation}

The method was fully validated to the EC Directive 2002/657 for eight of the nine cyanotoxins, with ATX-A only partially validated due to the presence of the amino acid phenylalanine (Phe). Since these compounds are isobaric and elute similarly, and with Phe naturally occurring in fish at high levels, the amount present in the tissue used for validation generally resulted in the two peaks almost merging into one peak whereby separation and integration was difficult. Consequently, with them sharing transitions, it was difficult to ascertain an accurate $\mathrm{CC}_{\alpha}$ (LOD) and $\mathrm{CC}_{\beta}(\mathrm{LOQ})$ for ATX-A. However, in the MS method, a second qualifier ion for ATX-X only was used as a diagnostic ion to prevent misidentification with Phe: $q 1=166.1>42.95$.

As no certified reference materials (CRMs) were used in validating the method and as the added analyte may not act as it does in a real sample, the EC Directive 2002/657 states that at the spiking level of $50 \mu \mathrm{g} / \mathrm{kg}(0.05 \mu \mathrm{g} / \mathrm{g})$ used, the minimum trueness tolerance has to be in the range -20 to $+10 \%$. However, it should also be stated that the toxin in real samples may not present for analysis in the same manner as that of the added standard. Similarities in masking may arise to those previously described for mycotoxins [31]. The added standard is freely available in the matrix, but toxin in the sample may be covalently bound or masked within the tissue as a non-covalent, associative interaction between toxin and matrix and, unless the extraction process releases the toxin in its free form, it may go undetected. Taking this into account, the resulting validation showed that the method was fit for purpose, with the data outlined in Table 2, including results for linearity $\left(r^{2}\right)$, absolute recovery, calculated conc., trueness, inter- and intraday precision analysis, $\mathrm{CC}_{\alpha}$ (LOD) and $\mathrm{CC}_{\beta}(\mathrm{LOQ})$. The $\mathrm{CC}_{\alpha}$ and $\mathrm{CC}_{\beta}$ values were based on the less intense qualifying ion (q) for all analytes, and with an injection volume of only $1 \mu \mathrm{L}$, the mean on-column $\mathrm{CC}_{\alpha}$ (LOD) and $\mathrm{CC}_{\beta}$ (LOQ) values are 0.9 and $1.5 \mu \mathrm{g} / \mathrm{kg} \mathrm{dw}(\mathrm{ppb})$, respectively.

\section{Field sample analysis}

\section{Aquaculture pond water}

Analysis of the water from the five aquaculture farms was considered as total toxin load as cells were lysed on lyophilisation and so included both intra- and extracellular toxin. Samples were not filtered on collection as a large proportion of CYN in toxic blooms of $C$. raciborskii has been reported as being extracellular [2]. Out of the five aquaculture 
Table 2 Results from the validation of the nine cyanotoxins in fish muscle to the EC Directive $2002 / 657$

\begin{tabular}{llllllll}
\hline Analyte & $\begin{array}{l}\text { Linearity } \\
\left(r^{2}\right)\end{array}$ & $\begin{array}{l}\text { Absolute } \\
\text { recovery } \\
(\%)\end{array}$ & $\begin{array}{l}\text { Trueness } \\
(\%)\end{array}$ & $\begin{array}{l}\text { Inter-day } \\
\text { repeatability } \\
(\mathrm{rsd} \%)\end{array}$ & $\begin{array}{l}\text { Intra-day } \\
\text { repeatability } \\
(\mathrm{rsd} \%)\end{array}$ & $\begin{array}{l}\mathrm{CC}_{\alpha}(\mu \mathrm{g} / \\
\left.\mathrm{kg} \mathrm{dw}^{\mathrm{b}}\right)\end{array}$ & $\begin{array}{l}\mathrm{CC}_{\beta}(\mu \mathrm{g} / \\
\left.\mathrm{kg} \mathrm{dw}^{\mathrm{b}}\right)\end{array}$ \\
\hline ATX-A & 0.999 & 57.7 & +1.8 & 4.2 & 3.8 & - & - \\
CYN & 0.999 & $99.2^{\mathrm{c}}$ & -0.2 & 2.0 & 1.7 & 1.8 & 2.7 \\
NOD & 0.999 & 83.1 & -2 & 7.7 & 4.9 & 0.4 & 0.8 \\
MC-RR & 0.999 & 87.6 & +6.8 & 4.7 & 4.4 & 1.1 & 1.5 \\
MC-LA & 0.997 & 76.5 & -2.8 & 7.0 & 6.2 & 0.6 & 0.9 \\
MC-LF & 0.999 & 75.2 & +7 & 5.2 & 4.7 & 1.4 & 2.1 \\
MC-LR & 0.998 & 80.3 & +3.6 & 5.7 & 5.1 & 0.5 & 0.8 \\
MC-LY & 0.998 & 76.9 & -0.4 & 8.3 & 6.5 & 1.0 & 1.8 \\
MC-YR & 0.999 & 78.5 & -5.2 & 7.5 & 4.4 & 0.7 & 1.4 \\
\hline
\end{tabular}

The table shows trueness, inter- and intra-day precision analysis ( $\mathrm{rsd} \%)$, linearity $\left(r^{2}\right)$, absolute recovery, $\mathrm{CC}_{\alpha}$ (LOD) and $\mathrm{CC}_{\beta}$ (LOQ)

${ }^{\text {a }}$ Absolute recovery is expressed as the extraction efficiency when spiked with $5 \mathrm{ng}$ of toxin per $100 \mathrm{mg}$ lyophilised fish muscle, equating to $50 \mathrm{ng} / \mathrm{g}(50 \mu \mathrm{g} / \mathrm{kg})$

${ }^{\mathrm{b}}$ Dry weight (after lyophilisation)

${ }^{\mathrm{c}}$ Corrected by the use of CYN (N $\left.{ }^{14} \rightarrow \mathrm{N}^{15}\right)$ internal standard farms tested, three $(60 \%)$ were found to contain cyanotoxins, with two testing positive for both CYN and MC-LR and the third containing CYN only. The levels observed were relatively low (Table 3) with the highest level detected being CYN at a level of $0.27 \mu \mathrm{g} / \mathrm{L}$ in farm 1-1. All concentrations found were below the recommended WHO limit of $1 \mu \mathrm{g} / \mathrm{L}$ set for freshwater [5], with the MC-LR level observed in farm 1-1 similar to that seen across four sampling sites from a Mexican lake (Lago de Patzcuaro) characterised by a persistent cyanobacterial bloom [21].

\section{Determination of free toxin(s) in fish samples}

A total of 34 fish (muscle tissue), 17 livers and 9 egg samples were extracted and analysed. A summary of those found to contain cyanotoxins is provided in Fig. 2. As the validation was only performed on fish muscle, the levels characterised in the liver and eggs can only be described as estimates. The results show four fish muscle (12\%), eight livers (47\%) and two eggs $(22 \%)$ were found to contain cyanotoxins, MC-LR and MC-LF as well as CYN. Only one cyanotoxin, MC-LR, was identified in the muscle of any of the fish tested, with all the positives found in aquaculture farm 1-1. In this farm, $80 \%$ of the tilapia sampled contained MC-LR with the levels detected in the fish muscle ranging from 13.4 to $16.8 \mu \mathrm{g} / \mathrm{kg} \mathrm{dw}$, with a mean level of $15.5 \mu \mathrm{g} / \mathrm{kg} \mathrm{dw}$.

The highest toxin levels identified in the tissues sampled were MC-LR at 16.8 and $45.2 \mu \mathrm{g} / \mathrm{kg} \mathrm{dw}$ in the muscle and liver, respectively; MC-LF at $11.8 \mu \mathrm{g} / \mathrm{kg} \mathrm{dw}$ in the liver only; and $\mathrm{CYN}$ at 103.4 and $46.9 \mu \mathrm{g} / \mathrm{kg} \mathrm{dw}$ in the liver and eggs, respectively. None of the fish muscle from farm 2-1 was positive for MC-LR, or any of the cyanotoxins studied, despite the water from this aquaculture farm having low levels of toxins present.

Of the five fish from farm 1-1, three livers were also excised and tested with the integrity of the other two livers compromised. Two of these livers showed high levels of cyanotoxins, with fish 3 containing MC congeners MC-LR and MC-LF, along with CYN, giving a combined estimated toxin load of $124.4 \mu \mathrm{g} / \mathrm{kg} \mathrm{dw}$. A second liver sample from farm 1-1, fish 4 showed the presence of MC-LR and CYN at levels of 93.5 and $103.4 \mu \mathrm{g} / \mathrm{kg} \mathrm{dw}$, respectively, giving a combined estimated toxin load of almost $200 \mu \mathrm{g} / \mathrm{kg} \mathrm{dw}$.

Of the 19 fish harvested from farm 2-1, 11 had their livers and/or eggs also removed and tested as a representative sample, with the other livers compromised by being stored frozen. Over $70 \%$ of the livers tested from farm 2-1 contained CYN and MC congeners MC-LR and MC-LF, with the highest levels detected of each estimated at 46.9, 45.2 and $11.8 \mu \mathrm{g} /$ $\mathrm{kg} \mathrm{dw}$, respectively. This analysis also identified CYN in the

Table 3 Results showing the levels and cyanotoxins found in the water from the aquaculture farms sampled

\begin{tabular}{lll}
\hline Farm I.D. & \multicolumn{2}{l}{ Toxin } \\
\cline { 2 - 3 } & CYN $(\mu \mathrm{g} / \mathrm{L})$ & MC-LR $(\mu \mathrm{g} / \mathrm{L})$ \\
\hline $1-1$ & 0.27 & 0.14 \\
$1-3$ & nd & nd \\
$1-4$ & nd & nd \\
$1-5$ & 0.02 & nd \\
$2-1$ & 0.19 & 0.08 \\
\hline
\end{tabular}

$n d$ not detected 
Fig. 2 Results of the free toxin levels detected in the muscle tissue, liver and eggs of the tilapia harvested from the aquaculture farms
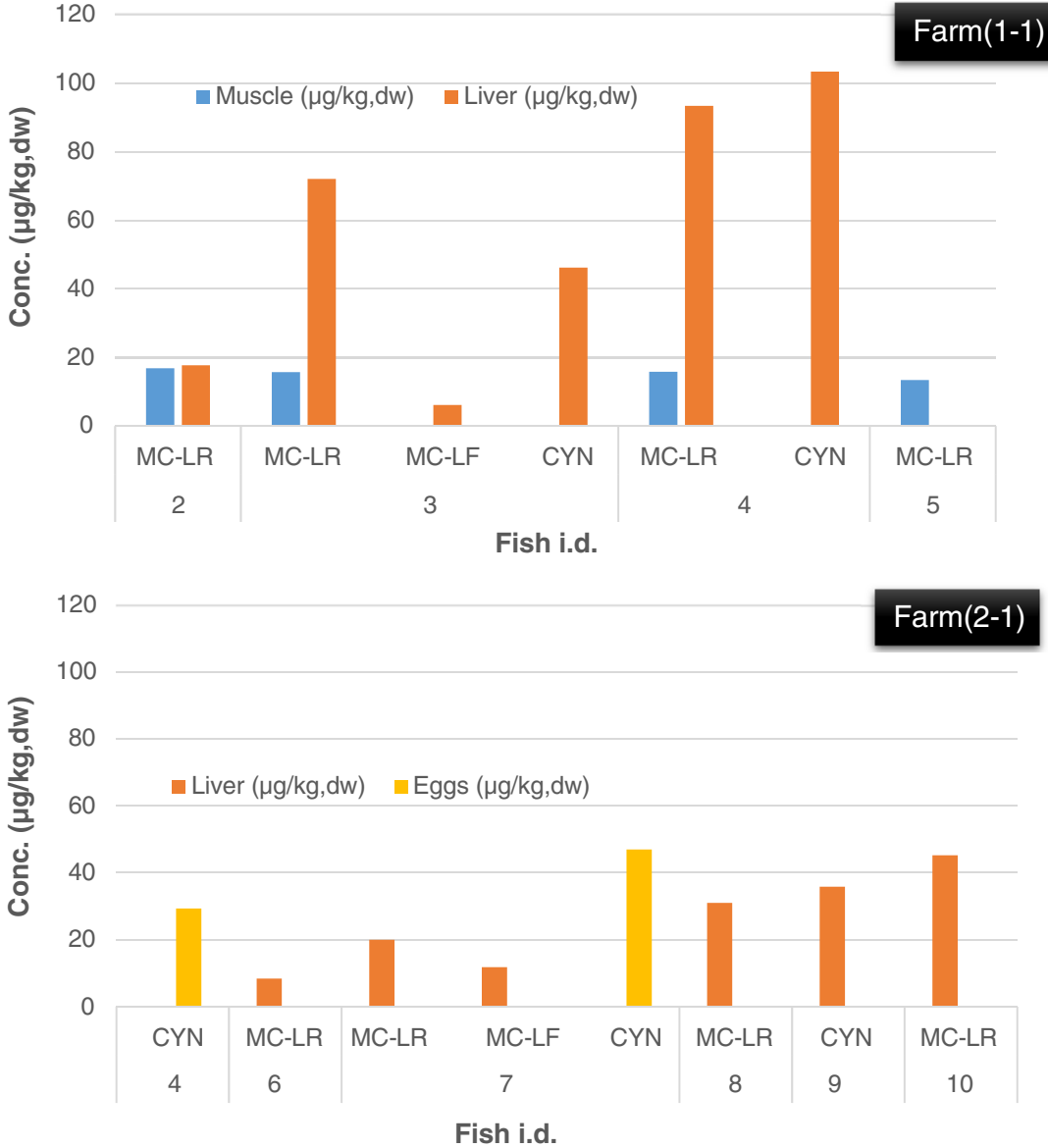

Concentration of cyanotoxin (MC-LR) detected in the muscle tissue of the Tilapia from farm (1-1).

Concentration of cyanotoxin(s) detected in the livers of the Tilapia from farms (1-1) and $(2-1)$.

Concentration of cyanotoxin(s) detected in the eggs of the Tilapia from farm (2-1). eggs of two fish from farm 2-1, with levels of 29.3 and $46.9 \mu \mathrm{g} / \mathrm{kg} \mathrm{dw}$ for fish 4 and 7 , respectively.

\section{Determination of total MC levels (free plus bound/conjugated)}

The results of the MMPB analysis (Fig. 3) showed the same four fish from aquaculture farm 1-1 contained MMPB, with the levels detected ranging from 10.6 to $16.2 \mu \mathrm{g} / \mathrm{kg} \mathrm{dw}$ and a mean estimated value of $13.0 \mu \mathrm{g} /$ $\mathrm{kg} \mathrm{dw}$. These levels account for the total level of MC present, i.e. protein-bound plus free MC. On conversion of the amount of MMPB observed to molar equivalents of MC-LR (100 ng MC-LR forms $21 \mathrm{ng}$ MMPB assuming $100 \%$ oxidation conversion), the level of MC-LR (or equivalents) detected equated to $50.7-77.4 \mu \mathrm{g} / \mathrm{kg} \mathrm{dw}$.
These values are based on an oxidation conversion efficiency of $55 \%$ as calculated on the day of extraction by the use of a control experiment, calculated by spiking control samples with MC-LR (100 ng) before oxidation to samples spiked with the corresponding amount of MMPB (21 ng) after oxidation. Accounting for losses due to incomplete oxidative conversion and calculating back to molar equivalents of MC-LR present, the levels range from 92.2 to $140.7 \mu \mathrm{g} / \mathrm{kg} \mathrm{dw}$, with a mean estimated value of $110.1 \mu \mathrm{g} / \mathrm{kg} \mathrm{dw}$.

\section{Determination of bound microcystin present}

With an average of $15.5 \mu \mathrm{g} / \mathrm{kg}$ dw of free MC-LR identified in the fish muscle and a mean estimated value of $110.1 \mu \mathrm{g} / \mathrm{kg} \mathrm{dw}$ of total MC present in the same tissue, the estimated mean 
Fig. 3 Results of the MMPB detected in fish from aquaculture farm 1-1 with the molar equivalents of MC-LR calculated

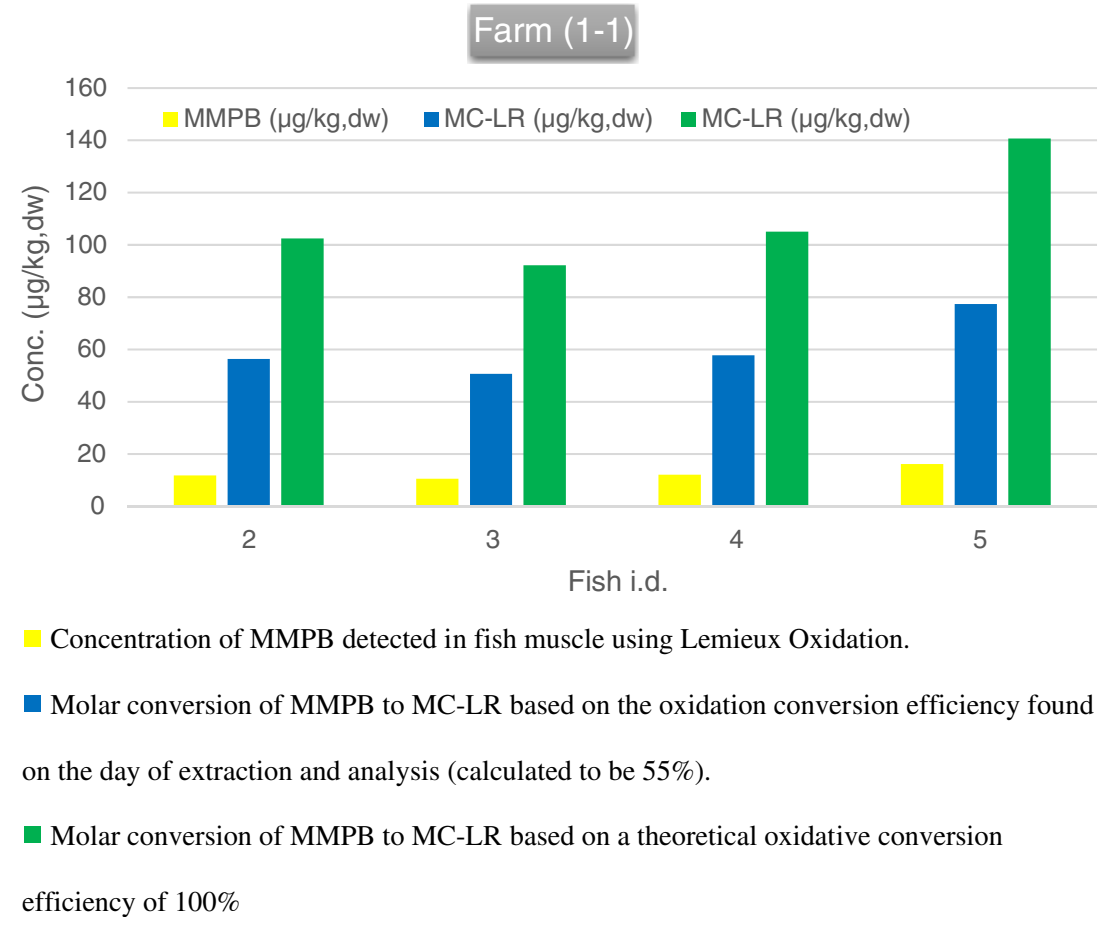

level of conjugated $\mathrm{MC}$ present in the muscle tissue equates to $94.7 \mu \mathrm{g} / \mathrm{kg} \mathrm{dw}$. Overall, the amount of conjugated or masked MC present accounts for $85 \%$ of the total.

\section{Bioaccumulation of MC in fish tissue}

Farm 1-1 shows the presence of MC-LR in the water body at $0.14 \mu \mathrm{g} / \mathrm{L}$ and in the muscle of the fish at an average level of $15.45 \mu \mathrm{g} / \mathrm{kg}$; therefore, the average bioaccumulation factor (BAF) taken at the time of harvest equates to 110 , with a BAF of $>1$ indicating bioaccumulation [32].

Taking the livers from farm 1-1, fish 2 shows a BAF of 126 for MC-LR, fish 3 has BAFs of 515 and 171 for MC-LR and CYN, respectively, whereas fish 4 shows BAFs of 667 and 383 for MC-LR and CYN, respectively. In comparison to fish livers taken from aquaculture farm 2-1 where the water was found to contain both MC-LR and CYN at levels of 0.08 and $0.19 \mu \mathrm{g} / \mathrm{L}$, fish $6,7,8$ and 10 indicate BAFs of 105, 250, 387 and 565, respectively, for MC-LR, with fish 9 indicating a BAF of 188 for CYN.

\section{Conversion of values from $d w$ to $w w$}

The level of toxin reported in the tilapia (O. niloticus) samples that were determined to be positive for free MC-LR in fish muscle from farm 1-1 ranged from 13.4 to $16.8 \mu \mathrm{g} / \mathrm{kg} \mathrm{dw}$, with a mean value of $15.5 \mu \mathrm{g} / \mathrm{kg} \mathrm{dw}$. As around $70 \%$ of fish tissue contains water and using a conversion factor of 0.31 to convert from dw to ww [33], this gives an average level of $4.8 \mu \mathrm{g} / \mathrm{kg} \mathrm{ww}$. The average total level of MC present as estimated by the use of Lemieux oxidation was $110.1 \mu \mathrm{g} / \mathrm{kg}$ $\mathrm{dw}$, which, when converted, equated to a value of $34.1 \mu \mathrm{g} / \mathrm{kg}$ ww, illustrating an estimated level of conjugated or masked MC of $29.3 \mu \mathrm{g} / \mathrm{kg}$ ww in the muscle tissue.

On evaluating the data generated from aquaculture farm 11, the level of MC-LR present in the water was $0.14 \mu \mathrm{g} / \mathrm{L}$, with the mean level of free MC-LR in fish muscle from this farm being $4.8 \mu \mathrm{g} / \mathrm{kg} \mathrm{ww}$, indicating that at the time of harvest, the fish there has a BAF of 34 [32]. It could be estimated that the total level of MC present in the O. niloticus at the time of harvest was $34.1 \mu \mathrm{g} / \mathrm{kg}$ ww accounting for masked microcystins, whereby the BAF would increase to 243.

\section{Discussion}

Several UPLC-MS/MS (or LC-MS/MS) methods have been published for the analysis of cyanotoxins in fish tissue, with these mainly determining MCs, NOD, CYN and ATX-A separately [19, 22, 23, 34-38]. However, to date, there have been no validated UPLC-MS/MS methods published for the determination of all the aforementioned cyanotoxins in fish muscle tissue, across three different classes of cyanotoxin, along with their combined extraction and sample enrichment, making this method novel.

An improvement over other published methods is performing the extraction and analysis in 1 day by the use of $75 \%$ aqueous methanol $(v / v)(0.5 \%$ acetic acid $v / v)$ as the extraction solvent in place of $\mathrm{BuOH} / \mathrm{MeOH} / \mathrm{H}_{2} \mathrm{O}(1: 4: 15)$ [23]. Extraction with $75 \%$ aqueous methanol $(v / v)(0.5 \%$ 
acetic acid) gave acceptable recoveries of the suite of cyanotoxins in comparison to $\mathrm{BuOH} / \mathrm{MeOH} / \mathrm{H}_{2} \mathrm{O}(1: 4: 15)$. Taking into account the extraction with $\mathrm{BuOH} / \mathrm{MeOH} / \mathrm{H}_{2} \mathrm{O}$ $(1: 4: 15)$ is usually performed over a total of $72 \mathrm{~h}(3 \times 24 \mathrm{~h}$ extractions) whereas the extraction with $75 \%$ aqueous methanol $(v / v)(0.5 \%$ acetic acid $v / v)$ took only $45 \mathrm{~min}$, it was decided to use the latter to develop the method, saving quite a bit of time.

The results from the analysis of the water samples from the five aquaculture farms showed the presence of cyanotoxins, with levels lower than those reported in studies carried out in Zaria, Northern Nigeria [20], and China [13, 19], but similar to levels reported from a freshwater lake in Mexico [21]. No reports outlining the presence of CYN in aquaculture systems have been identified to date; however, this cyanotoxin was found in $60 \%$ of those sampled in the present study. The water samples taken from the five aquaculture farms were all obtained at the time of harvesting the fish, and no further information was provided as to when (if) HABs had occurred. It is, however, likely that farm 1-1 had a bloom in its senescent phase, allowing the fish more time to bioaccumulate released toxin.

Four of the five fish sampled from farm 1-1 accumulated MC-LR, the most acutely toxic variant of the MC congeners. Based on the WHO tolerable daily intake (TDI) value for MCLR of $0.04 \mu \mathrm{g} / \mathrm{kg}$ body weight per day [5], the estimated daily intake (EDI) of MCs for an adult weighing $60 \mathrm{~kg}$ and consuming $300 \mathrm{~g}$ of edible organs of aquatic animals equates to $2.4 \mu \mathrm{g}$ MC-LR per day for safe consumption. Taking the mean level of MC-LR found in the edible portion of the O. niloticus at $15.45 \mu \mathrm{g} / \mathrm{kg} \mathrm{dw}$, the exposure from this equates to $4.65 \mu \mathrm{g}$ MC-LR, almost twice the level deemed safe by the WHO. Taking the estimated mean level of $110.1 \mu \mathrm{g} / \mathrm{kg}$ dw of total MC detected, based on the amount of MMPB detected and corrected for losses due to oxidative conversion, this gives a mean EDI of $33 \mu \mathrm{g}$ MCs present in the O. niloticus. Based on the TDI for MC-LR calculated above, this value is close to 14 times greater and, as such, constitutes a severe health risk if consumed.

On evaluating the levels reported in $\mathrm{dw}$ for free MC-LR and converting to ww using a conversion factor of 0.31 [33], the EDI value for the edible portion of the $O$. niloticus equates to $1.4 \mu \mathrm{g}$, lower than the safe consumption level suggested by the WHO of $2.4 \mu \mathrm{g}$ MC-LR. However, considering the total amount of MC present as estimated by the amount of MMPB detected and the conversion to ww using the same coefficient factor of 0.31 , the EDI for consumption of muscle tissue in the $O$. niloticus from this study equates to $10.2 \mu \mathrm{g}, 4.25$ times higher than that deemed safe by the WHO.

In relation to the estimated level of $29.4 \mu \mathrm{g} / \mathrm{kg}$ ww $(94.7 \mu \mathrm{g} / \mathrm{kg} \mathrm{dw})$ of conjugated or masked MC calculated in the muscle tissue ("Determination of bound microcystin present" section), it must be noted that the extra MC detected by Lemieux oxidation may not be exclusively from protein- bound MCs through their interaction with PP1 and PP2A as stated previously [26]. Instead, the extra MC(s) detected may be from congeners the method does not detect, with over 100 characterised to date [3], as well as from protein-bound MC. Although the other congeners which may be present may not be as toxic as MC-LR, they are still likely to pose a health risk to consumers and could lead to synergistic effects between different congeners, potentially increasing the toxicity [11]. It must also be considered that these values are based on adult consumption so the exposure is likely to be much more dangerous for children. Furthermore, BAFs calculated show bioaccumulation in the muscle and liver with both tissues having BAFs of $>1$. The livers show BAFs of up to six times higher than that of the muscle which is expected with it being the target organ; however, as the method was not validated for liver tissue, this is only an estimate.

A study conducted by Jia et al. [23] reported that two omnivorous fish species harvested from Lake Taihu in China contained three MC congeners: MC-LR, MC-YR and MCRR with combined levels of 26.7 and $31.7 \mathrm{ng} / \mathrm{g} \mathrm{dw}$, higher than the mean level found in the muscle of the present study. However, they found MC-RR to be the most prevalent (60$100 \%$ ) in the samples tested. The level of MC-LR detected in the present study was approximately 5 -times higher than that of Jia et al. [23], and with the $\mathrm{LD}_{50}$ in mice for MC-RR being approximately 10-fold higher than for MC-LR [5, 39], the toxicity of the $O$. niloticus from this aquaculture farm would be substantially higher. The literature also shows that differing levels and types of MCs have been found in different species of farmed fish [23, 35], with the omnivorous Carassius auratus in the study by Zhang et al. [35] showing MCs in the muscle tissue with a maximum value of $13 \mu \mathrm{g} / \mathrm{kg} \mathrm{dw}$ and an average of $2.4 \mu \mathrm{g} / \mathrm{kg} \mathrm{dw}$, just over six times lower than that found in the $O$. niloticus of the present study. Again, the majority of $\mathrm{MC}$ detected in the muscle of the $C$. auratus was MC-RR, whereas that detected in the O. niloticus from this study was MC-LR.

Research conducted by Poste et al. [33] looked at several fish species, including $O$. niloticus, across several tropical (Ugandan) and temperate (North American) freshwater lakes. They detected MCs in the muscle tissue of $O$. niloticus harvested from a number of these lakes, showing an average level of $11 \mu \mathrm{g} / \mathrm{kg}$ ww, just over twice that found in the O. niloticus from our study when converted to ww. In their study, detection was performed by ELISA using a MC-Adda antibody, meaning that the individual congeners present could not be elucidated, and as such, the toxicity of these fish may not be as high due to some congeners having a higher $\mathrm{LD}_{50}$ value than $\mathrm{MC}$ LR [33]. A further study carried out by Gurbuz et al. [40] also showed accumulation of MCs in the muscle and liver tissue in two omnivorous fish species, Cyprinus carpio and Carassius gibelio, with one of the fish species, C. carpio, showing significantly higher concentrations of MC in the liver over the 
muscle, similar to that seen in our study, whereas no significant difference was found between tissues in C. gibelio [40].

All of the above reports, including those conducted by Zhang et al. [35], Magalhaes et al. [22] and Chen et al. [34] all looked at free MC levels and did not evaluate the level of total MC present. It has been reported that the potential amount of covalently bound MCs can account for between 38 and $99 \%$ of the total MC present in an organism's tissue. With this study showing up to $85 \%$ of the MC in the muscle tissue of the farmed fish was possibly conjugated or masked, the total levels present and subsequent exposure reported could be significantly higher. One caveat of this is that covalently bound $\mathrm{MC}$ may not be as readily bioavailable and therefore not be as toxic. One study by Smith et al. [41] looked at MC-phosphatase peptides produced by proteolytic digestion, mimicking the human gut. They concluded that these products were less toxic in vitro [41]. Importantly though, they were still deemed toxic and would only add to the toxicity conferred by any free MC present.

The study conducted by Chen et al. [13] on fishermen living off Lake Taihu showed MC in the muscle of 16 aquatic species and in the serum of the fishermen, with the proportions of the MC congeners in the blood matching that in the muscle of the fish. This also led to liver damage in these men with their liver function enzymes elevated. This demonstrates that eating fish contaminated with MC will result in the uptake of the toxin, with the health risks relatively unknown apart from the growing links to liver and colorectal cancers [7, 15].

Liver tissue contained the highest amount of toxin in the tissues tested, with estimated levels of 45.2 and $103.4 \mu \mathrm{g} / \mathrm{kg}$ $\mathrm{dw}$ for MC-LR and CYN, respectively. This is not surprising considering both MC-LR and CYN are considered hepatotoxic, with the liver being the primary target organ. As $O$. niloticus like many other fish may also be consumed whole [32], the levels that an individual could be exposed to will be substantially higher than for consumption of the muscle only, especially taking into account the levels seen in the livers of the $O$. niloticus from this study, and could constitute a severe health risk to human health.

This is also the first report of the presence of CYN in the eggs of fish, identified in two fish from farm 2-1, with estimated levels of 29.3 and $46.9 \mu \mathrm{g} / \mathrm{kg}$ dw for fish 4 and 7 , respectively. This may have consequences for the development and viability of embryos and/or the fry if passed on during reproduction [42], not to mention the economic consequences to the farmer.

Furthermore, a number of livers and eggs from farms 1-1 and 2-1 showed the presence of another peak in the same retention window as MC-YR; however, the exact retention time and ion ratio $(q / Q)$ were not the same as those of the MC-YR standard. This points to the possibility of the presence of a further MC analogue, MC-RY, recently identified in a cyanobacterial bloom from Lake Victoria, Tanzania. This
MC congener, MC-RY, has been reported in freshwater systems in African countries such as Uganda, Kenya and Tanzania [43], with this study indicating its potential presence in fish in SE Asian aquaculture.

\section{Conclusion}

A method was developed and validated for the measurement of nine cyanotoxins in fish muscle tissue, also used to measure free cyanotoxin levels in fish liver and eggs, from a number of typical pond-based aquaculture farms in SE Asia. In one of the farms studied, the levels of free MC-LR present were lower than the level deemed safe by the WHO. When the total MC level is taken into account, the toxin present was on average around four times higher than the recommended WHO TDI, indicating that a substantial proportion of MCs are masked and that the levels reported in the literature are more than likely vastly underestimated. Even though the levels of free MC-LR found indicate that the fish are safe to eat, the levels of total MC estimated from this study show the opposite. These data do, however, indicate that consumption of such contaminated fish constitutes a severe health risk, especially if eaten whole due to the levels detected in the fish livers. There is also the possibility that consumption of fish contaminated with MC-LR could lead to liver cancer due to chronic long-term exposure. With climate change and eutrophication on the increase globally, the subsequent rise in HABs across freshwater systems which are increasingly used for aquaculture, the potential for largescale contamination of fish by freshwater cyanotoxins raised in aquaculture systems appears likely. Those who are of particular concern are fishing communities, whereby the consumption of water and fish from fresh water bodies subjected to dense HABs constitutes a health risk due to chronic exposure year-round from MCs and other cyanotoxins. This study indicates that further monitoring and control of the effects of HABS and cyanotoxins on the safety of farmed fish is required and this may lead to the need for regulations to be put in place in aquaculture systems. There also appears the need for total microcystin levels to be quantified due to the majority of the microcystins present in the fish being masked, similar to mycotoxins where food safety legislation is being rethought due to this issue.

Acknowledgements The authors would like to acknowledge the contributions of collaborators on this project: Katrin Kittler from the BAM Federal Institute for Materials Research and Testing, Richard-WillstätterStraße 11, 12489 Berlin, Germany.

This research was funded by the Advanced ASSET project, partly funded through Invest NI and from the European Sustainable Programme 2007-2013 under the European Regional Development Fund (ERDF). 
Compliance with ethical standards All fish sampling undertaken in SE Asia complied with their institutional and national guidelines. The collection of fish samples complied with the UK Animals (Scientific Procedures) Act 1986 and associated EU Directive 2010/63/EU for animal experiments.

Conflict of interest The authors declare that they have no conflict of interest.

Open Access This article is distributed under the terms of the Creative Commons Attribution 4.0 International License (http:// creativecommons.org/licenses/by/4.0/), which permits unrestricted use, distribution, and reproduction in any medium, provided you give appropriate credit to the original author(s) and the source, provide a link to the Creative Commons license, and indicate if changes were made.

\section{References}

1. Codd GA, Morrison LF, Metcalf JS. Cyanobacterial toxins: risk management for health protection. Toxicol Appl Pharmacol. 2005; doi:10.1016/j.taap.2004.02.016.

2. van Apeldoorn ME, van Egmond HP, Speijers GJA, Bakker GJI. Toxins of cyanobacteria. Mol Nutr Food Res. 2007; doi:10.1002/ mnfr.200600185.

3. Roegner AF, Brena B, Gonzalez-Sapienza G, Puschner B. Microcystins in potable surface waters: toxic effects and removal strategies. J Appl Toxicol. 2014; doi:10.1002/jat.2920.

4. Greer B, McNamee SE, Boots B, Cimarelli L, Guillebault D, Helmi K, Marcheggiani S, Panaiotov S, Breitenbach U, Akcaalan R, Medlin LK, Kittler K, Elliott CT, Campbell K. A validated UPLC-MS/MS method for the surveillance of ten aquatic biotoxins in European brackish and freshwater systems. Harmful Algae. 2016; doi:10.1016/j.hal.2016.01.006.

5. Sivonen K, Jones G (1999) In: Chorus I, Bartram J (eds) Toxic cyanobacteria in water: a guide to their public health consequences, monitoring and management. Cyanobacterial toxins. E \& FN Spon, WHO. 41-111.

6. Eriksson JE, Toivola D, Meriluoto JAO, Karaki H, Han YG, Hartshorne D. Hepatocyte deformation induced by cyanobacterial toxins reflects inhibition of protein phosphatases. Biochem Biophys Res Commun. 1990; doi:10.1016/S0006291X(05)80936-2.

7. World Health Organisation, International Agency for Research on Cancer. IARC monographs on the evaluation of carcinogenic risks to humans, No. 94. Ingested nitrate and nitrite, and cyanobacterial peptide toxins. IARC Monogr. Eval. Carcinog. Risks Hum. 2010.

8. Moreira C, Azevedo J, Antunes A, Vasconcelos V. Cylindrospermopsin: occurrence, methods of detection and toxicology. J Appl Microbiol. 2013; doi:10.1111/jam.12048.

9. Merel S, Clement M, Thomas O. State of the art on cyanotoxins in water and their behaviour towards chlorine. Toxicon. 2010; doi:10. 1016/j.toxicon.2009.10.028.

10. Pouria S, de Andrade A, Barbosa J, Cavalcanti RL, Barreto VTS, Ward CJ, Preiser W, Poon GK, Neild GH, Codd GA. Fatal microcystin intoxication in haemodialysis unit in Caruaru. Brazil Lancet. 1998; doi:10.1016/S0140-6736(97)12285-1.

11. Ferrao-Filho AS, Kozlowsky-Suzuki B. Cyanotoxins: bioaccumulation and effects on aquatic animals. Mar Drugs. 2011; doi:10. 3390/md9122729.

12. Mulvenna V, Dale K, Priestly B, Mueller U, Humpage A, Shaw G, Allinson G, Falconer I. Health risk assessment for cyanobacterial toxins in seafood. Int J Environ Res Public Health. 2012; doi:10. 3390/ijerph9030807.

13. Chen J, Xie P, Li L, Xu J. First identification of the hepatotoxic microcystins in the serum of a chronically exposed human population together with indication of hepatocellular damage. Toxicol Sci. 2009; doi:10.1093/toxsci/kfp009.

14. Falconer IR. Tumor promotion and liver-injury caused by oral consumption of cyanobacteria. Environ Toxicol Water Qual. 1991; doi: 10.1002/tox.2530060207.

15. Miao C, Ren Y, Chen M, Wang Z, Wang T. Microcystin-LR promotes migration and invasion of colorectal cancer through matrix metalloproteinase-13 up-regulation. Mol Carcinog. 2016; doi:10. 1002/mc.22298.

16. Lin H, Liu W, Zeng H, Pu C, Zhang R, Qiu Z, Chen J, Wang L, Tan Y, Zheng C, Yang X, Tian Y, Huang Y, Luo J, Luo Y, Feng X, Xiao G, Feng L, Li H, Wang F, Yuan C, Wang J, Zhou Z, Wei T, Zuo Y, Wu L, He L, Guo Y, Shu W. Determination of environmental exposure to microcystin and aflatoxin as a risk for renal function based on 5493 rural people in Southwest China. Environ. Sci. Technol. 2016; doi:10.1021/acs.est.6b01062.

17. Food and agriculture Organization of the United Nations. The state of world fisheries and aquaculture 2016. Contributing to food security and nutrition for all . Rome: FAO; $2016.200 \mathrm{pp}$

18. O'Neil JM, Davis TW, Burford MA, Gobler CJ. The rise of harmful cyanobacteria blooms: the potential roles of eutrophication and climate change. Harmful Algae. 2012; doi:10.1016/j.hal.2011.10.027.

19. Peng L, Liu Y, Chen W, Liu L, Kent M, Song L. Health risks associated with consumption of microcystin-contaminated fish and shellfish in three Chinese lakes: significance for freshwater aquacultures. Ecotoxicol Environ Saf. 2010; doi:10.1016/j.ecoenv. 2010.07.043.

20. Chia AM, Oniye SJ, Ladan Z, Lado Z, Pila AE, Inekwe VU, Mmerole JU (2009) A survey for the presence of microcystins in aquaculture ponds in Zaria, Northern-Nigeria: possible public health implication. Afr. J. Biotechnol

21. Berry JP, Lee E, Walton K, Wilson AE, Bernal-Brooks F. Bioaccumulation of microcystins by fish associated with a persistent cyanobacterial bloom in Lago de Patzcuaro (Michoacan, Mexico). Environ Toxicol Chem. 2011; doi:10.1002/etc.548.

22. Magalhaes VF, Marinho MM, Domingos P, Oliveira AC, Costa SM, Azevedo LO, Azevedo SMFO. Microcystins (cyanobacteria hepatotoxins) bioaccumulation in fish and crustaceans from Sepetiba Bay (Brasil, RJ). Toxicon. 2003; doi:10.1016/S00410101(03)00144-2.

23. Jia J, Luo W, Lu Y, Giesy JP. Bioaccumulation of microcystins (MCs) in four fish species from Lake Taihu, China: assessment of risks to humans. Sci Total Environ. 2014; doi:10.1016/j.scitotenv. 2014.04.037.

24. Saker ML, Eaglesham GK. The accumulation of cylindrospermopsin from the cyanobacterium Cylindrospermopsis raciborskii in tissues of the redclaw crayfish Cherax quandricarinatus. Toxicon. 1999; doi:10.1016/S0041-0101(98)00240-2.

25. Berry JP, Jaja-Chimedza A, Davalos-Lind L, Lind O. Apparent bioaccumulation of cylindrospermopsin and paralytic shellfish toxins by finfish in Lake Catemaco (Veracruz, Mexico). Food Addit Contam, Part A. 2012; doi:10.1080/19440049.2011.597785.

26. Neffling M, Lance E, Meriluoto J. Detection of free and covalently bound microcystins in animal tissues by liquid chromatographytandem mass spectrometry. Environ Pollut. 2010; doi:10.1016/j. envpol.2009.10.023.

27. Oehrle SA, Southwell B, Westrick J. Detection of various freshwater cyanobacterial toxins using ultra-performance liquid chromatography tandem mass spectrometry. Toxicon. 2010; doi:10.1016/j. toxicon.2009.10.001.

28. Msagati TAM, Siame BA, Shushu DD. Evaluation of methods for the isolation, detection and quantification of cyanobacterial 
hepatotoxins. Aquat Toxicol. 2006; doi:10.1016/j.aquatox.2006.03. 011.

29. Wormer L, Carrasco D, Cires S, Quesada A (2009) Advances in solid phase extraction of the cyanobacterial toxin cylindrospermopsin. Limnol. Oceanogr: Methods

30. The Commission of the European Communities (2002) Commission Decision No 657 of 12 August 2002, Implementing Council Directive 96/23/EC concerning the performance of analytical methods and the interpretation of results. Official Journal of the European Communities, L 221/8- L 221/36

31. Berthiller F, Maragos C, Dall'Asta C (2015) In: Dall'Asta C, Berthiller F (eds) Masked mycotoxins in food: formation, occurrence and toxicological relevance. Introduction to masked mycotoxins. The Royal Society of Chemistry, pp. 1-13. Doi: 10.1039/ 9781782622574-00001

32. Ibelings BW, Chorus I. Accumulation of cyanobacterial toxins in freshwater "seafood" and its consequences for public health: a review. Environ Pollut. 2007; doi:10.1016/j.envpol.2007.04.012.

33. Poste AE, Hecky RE, Guildford SJ. Evaluating microcystin exposure risk through fish consumption. Environ Sci Technol. 2011; doi: $10.1021 / \mathrm{es} 200285 \mathrm{c}$.

34. Chen J, Xie P, Zhang D, Ke Z, Yang H. In situ studies on the bioaccumulation of microcystins in the phytoplanktivorous silver carp (Hypophthalmichthys molitrix) stocked in Lake Taihu with dense toxic Microcystis blooms. Aquaculture. 2006; doi:10.1016/ j.aquaculture.2006.08.028.

35. Zhang D, Xie P, Liu Y, Qiu T. Transfer, distribution and bioaccumulation of microcystins in the aquatic food web in Lake Taihu, China, with potential risks to human health. Sci Total Environ. 2009; doi:10.1016/j.scitotenv.2008.12.039.

36. Guzman-Guillen R, Moreno I, Prieto Ortega AI, Eugenia SoriaDiaz M, Vasconcelos V, Camean AM. CYN determination in ?tissues from freshwater fish by LC-MS/MS: validation and application in tissues from subchronically exposed tilapia (Oreochromis niloticus). Talanta. 2015; doi:10.1016/j.talanta.2014.07.091.

37. Stewart I, Eaglesham GK, McGregor GB, Chong R, Seawright AA, Wickramasinghe WA, Sadler R, Hunt L, Graham G. First report of a toxic Nodularia spumigena (Nostocales/Cyanobacteria) bloom in sub-tropical Australia. II. Bioaccumulation of nodularin in isolated populations of mullet (Mugilidae). Int J Environ Res Public Health. 2012; doi:10.3390/ijerph9072412.

38. Bogialli S, Bruno M, Curini R, Di Corcia A, Lagana A. Simple and rapid determination of anatoxin - $\mathrm{a}$ in lake water and fish muscle tissue by liquid-chromatography-tandem mass spectrometry. J Chromatogr A. 2006; doi:10.1016/j.chroma.2006.04.064.

39. Drobac D, Tokodi N, Lujic J, Marinovic Z, Subakov-Simic G, Dulic T, Vazic T, Nybom S, Meriluoto J, Codd GA, Svircev Z. Cyanobacteria and cyanotoxins in fishponds and their effects on fish tissue. Harmful Algae. 2016; doi:10.1016/j.hal.2016.02.007.

40. Gurbuz F, Uzunmehmetoglu OY, Diler O, Metcalf JS, Codd GA. Occurrence of microcystins in water, bloom, sediment and fish from a public water supply. SciTotal Environ. 2016; doi:10.1016/j. scitotenv.2016.04.027.

41. Smith JL, Schulz KL, Zimba PV, Boyer GL. Possible mechanism for the foodweb transfer of covalently bound microcystins. Ecotoxicol Environ Saf. 2010; doi:10.1016/j.ecoenv.2009.12.003.

42. Rogers EH, Zehr RD, Gage MI, Humpage AR, Falconer IR, Marr $\mathrm{M}$, Chernoff $\mathrm{N}$. The cyanobacterial toxin, cylindrospermopsin, induces fetal toxicity in the mouse after exposure late in gestation. Toxicon. 2007; doi:10.1016/j.toxicon.2006.12.009.

43. Miles CO, Sandvik M, Nonga HE, Rundberget T, Wilkins AL, Rise F, Ballot A. Identification of microcystins in a Lake Victoria cyanobacterial bloom using LC-MS with thiol derivatization. Toxicon. 2013; doi:10.1016/j.toxicon.2013.03.016. 